\title{
Customer service in appliance sales departments of selected prominent retail outlets: Store man- ager, sales personnel and customer perspectives
}

\author{
Alet C Erasmus*
}

\begin{abstract}
OPSOMMING
Handelaars se nimmereindigende stryd om in ' $n$ hoogs kompeterende markomgewing sukses te behaal, verklaar waarskynlik waarom hulle neig om sekere elemente van hulle dienslewering te beklemtoon. Hierdie onderwerp word dus al vir 'n geruime tyd wêreldwyd deur navorsers bestudeer, veral deur ondersoeke na dienskwaliteit as aanduiding van uitnemende dienslewering. Om te verseker dat verskillende rolspelers betrek word, het hierdie navorsing in drie opeenvolgende fases ondersoek ingestel na die dienslewering van prominente afdelingswinkels in Tshwane, RSA waar huishoudelike toerusting verkoop word. Winkelbestuurders het tasbare bewys van die dienslewering in hulle eie winkels beoordeel; verbruikers $(\mathrm{N}=296)$ se persepsie van die dienskwaliteit van handelaars is ondersoek direk nadat ' $n$ aankooptransaksie voltrek is; en verkoopspersoneel het op grond van hulle eie ervaring deur middel van projektiewe tegnieke voorstelle gemaak oor hoe dienslewering verbeter kan word om verbruikers te bemagtig om ingeligte, verantwoordelike verbruikersbesluite te maak.
\end{abstract}

Winkelbestuurders het spesifieke tekortkominge in hulle onderskeie winkels geïdentifiseer. ' $n$ Enkelvoudige meting van verbruikers se persepsie van dienskwaliteit het getoon dat verbruikers se beoordeling van dienskwaliteit redelik simplisties, maar meerendeels positief is. Verkennende faktorontleding het tot ' $n$ ineenstorting van die oorspronklike vyf dimensies van die dienskwaliteitskaal na slegs twee dimensies gelei en hulle is in ooreenstemming met die onderskeie iteminhoud as die Ondersteuning en Indrukwekkendheid van dienslewering benoem. Verbruikers se positiewe beoordeling van dienskwaliteit is teenstrydig met die aanbevelings wat verkoopspersoneel in die projektiewe tegniek gemaak het om dienslewering te verbeter sodat verbruikers in staat sou wees om ingeligte verantwoordelike verbruikersbesluite te kan maak. Dit blyk dat verbruikers in ontluikende ekonomieë meer verdraagsaam is ten opsigte van swakker dienslewering, moontlik as gevolg van laer verwagtinge. Die aanbeveling is dat handelaars meer aandag aan elemente van dienslewering gee wat spesifiek met verbruikersopvoeding verband hou. Vervolgens behoort die potensiaal van verkoopspersoneel erken te word, veral ten opsigte van hulle rol tydens die fasilitering van verbruikers se aankoopbesluite, mits hulle werksomstandighede ook verbeter en hulle formeel geleentheid gebied word om opleiding te ontvang.
- Prof AC Erasmus*

Department of Consumer Science

University of Pretoria

Pretoria

Tel: $+27(0) 124203548$

Fax: +27 (0)12420 2855

E-mail: alet.erasmus@up.ac.za

* Corresponding author 


\section{INTRODUCTION AND JUSTIFICATION OF THE RESEARCH}

Service quality in retail has been a topic of investigation for many years and extensive effort has gone into the validation of models, instruments and scales that could be used to operationalise this phenomenon. Several service quality models exist: e.g. the Grönroos model that was developed in 1982/ 1984; Parasuraman et al's SERVQUAL model (1985); Cronin and Taylor's SERVPERF (Service Performance model: 1992); Dabholkar et al's RSQS (Retail Service Quality model: 1996), and more recently, the Brady and Cronin model (2001) (Martinez \& Martinez, 2010). Two models that have been used extensively to judge service quality in retail in the past are Parasuraman and co workers' SERVQUAL instrument and the amended version designed by Dabholkar and co workers. Service quality scales infer quality in perception and predominantly include intangible elements of service quality that are relevant during a buying encounter. Service quality per se, is however difficult to measure for two main reasons, namely the intangibility of the construct and its dimensions, and because consumers' judgements of service quality are based on their perceptions that are framed within their expectations that are not necessarily realistic or reasonable.

Several researchers have however expressed the need to redefine service quality within context, within a specific product category and with a specific population in mind (Williams, 2002; Winsted, 1997). Malhotra et al (1994) for example postulate that there are significant differences between the perception and practical implementation of the dimensions of service quality between developed and developing countries. They specifically caution against a standardised marketing approach and postulate that customers in developed countries tend to judge service reliability in terms of its trustworthiness and accuracy, while consumers in developing countries are more inclined to attend to human related aspects such as the assistance of personnel. This study therefore aimed to investigate consumers' perception of service quality in appliance sales (the product category), in major retail stores in an urban area (the context) in South Africa as an example of an emerging economy (the specific population). An emerging economy is described as moving toward a market based economy and although such an economy does not necessarily account for a significant part of global wealth, it shows potential of becoming a lucrative market in the future (Reardon, 2005; Chan \& Cui, 2004). Consumers in these societies are also exposed to modern marketing practices brought about by economic reform and the influx of foreign businesses (Chan \& Cui, 2004).

A major challenge that retailers have had to deal with in South Africa in recent years is the diversity of customers who enter their stores. Major retailers have to accommodate differences in the functional literacy and structural knowledge of consumers across a broad socio economic spectrum. The situation has become even more complex since 1994 due to signifi- cant socio political changes that have enabled millions of households to migrate from poverty levels into middle income groups within a relative short period of time (Black spending power on the way up, 2004; Wortley \& Tshwaedi, 2002). This has created a structural evolution in the consumer market that has changed the profile of the South African consumer that drives the economy (Bisseker, 2004; Haupt, 2001). A prominent consumer segment that is financially more secure but lacks consumer related exposure and experience that is required to act confidently in the market place, has evolved (Nieftagodien \& Van der Berg, 2007). This presents specific challenges for retail in terms of efforts to support the needs and requirements of consumers to conclude informed, responsible buying decisions. A further complication is that global influences enable exposure to brands and product ranges in retail in South Africa that compare favourably with what stores offer in advanced Firstworld countries. Basson in Dakora et al (2010) is of the opinion that many operations need to change for South African retailers to work well in this global village. At present, the white-goods industry in South Africa (i.e. major household appliances that is regarded a high-risk product category due to the financial, performance and social risk that are relevant during a purchase decision) is predominantly importorientated. When entering the appliance section in a major retail store, consumers are hence confronted with an overwhelming array of products in terms of price, brands and models. Even experienced consumers may find themselves in awe because household technology has changed so rapidly in recent years that prior experience not necessary provides the solutions to uncertainties that may arise during product evaluation. Ideally the service offering in retail stores should thus be of such a nature that it counteracts confusion during consumers' evaluation of product alternatives and facilitates opportunity for consumers to conclude informed, responsible buying decisions that would improve consumer satisfaction and ultimately also encourage customers' return intentions.

\section{RESEARCH PROBLEM}

Retail in South Africa finds itself in a paradoxical situation because the majority of the population bears distinct characteristics of an emerging economy although the market itself is strongly influenced by internationalization of retail (Park \& Sternquist, 2008) that is characteristic of global business (Myers \& Alexander, 2007). According to McGarriagle in Dakora et al (2010) globalisation provides major opportunities for retail, which probably explains why retailers across South Africa for example stock household appliances that closely resemble the options that are available in a First-world scenario. Prominent retailers across South Africa however also deal with consumers from a broad socio economic spectrum that differ in terms of product related exposure and experience. Consumers' ability to cope with complex and high risk buying decisions in the market place therefore differ vastly and when they encounter problems in the market place, they would (as described by Chan and Cui, 2004), not necessarily exercise their rights or engage 
in disapproving behaviour. As a consequence, retailers are not necessarily aware of shortcomings in their service offering.

From a marketing point of view, the ideal would be for the service offering of retail stores to boost consumers' satisfaction and encourage customers' return intentions. Little research has however been done to date to describe the specific challenges and problems that are encountered in South African retail as a result of retail internationalization (McGarriagle, 2008 in Dakora et al, 2010). From consumers' perspective, it is hoped that apart from consumer satisfaction, the service offering in retail would set conditions that are conducive for informed, responsible buying decisions. Empirical evidence of consumers' perception of the service quality in retail is therefore necessary to identify shortcomings in the service offering that could be used to direct retailers' efforts to augment their service offering in accordance with the expectations and needs of the diverse consumer population in South Africa. Efforts to investigate service quality in the context of an emerging economy may however be problematic. Extant research suggests that consumers with lower education levels have lower quality expectations and that they are consequently more tolerant of ineffective services compared to their counterpart in developed countries or more experienced, sophisticated patrons of the same store (Henry \& Caldwell, 2006; Malhotra et al, 1994). In the context of an emerging economy a favourable judgment of a retailer's service offering through an established instrument such as SERVQUAL may thus signify that "all is well in paradise" despite pertinent shortcomings. This notion was supported in a preceding report (Erasmus \& Gothan, 2008) of this research project that specifically dealt with customers' satisfaction with the customer service in appliance sales departments of prominent retail stores in Tshwane, RSA. Findings revealed that customers' product knowledge (when tested in the store immediately after a service encounter that resulted in the closure of a sales deal) contradicted their positive satisfaction judgements of tangible evidence, i.e. controllable evidence of the service offering. Customers' knowledge of the basic performance characteristics of their newly purchased appliances was below average although their judgement of the service offering was favourable. This contradiction signals a discrepancy that should be addressed to the benefit of all.

\section{RESEARCH OBJECTIVES}

Following a previous report on customers' satisfaction with tangible evidence of the service offering in appliance sales departments in prominent retail stores in Tshwane, RSA, this report deals with the judgements of three prominent role players in the fore mentioned sales context, i.e. an investigation and discussion of: (1) customers' perception of the service offering through implementation of an adapted version of a service quality instrument (adapted from Dabholkar et al, 1996);

(2) store managers' evaluation of the service offering in their respective stores as an indication of their awareness of shortcomings, and

(3) salespeople's recommendations for the optimisation of the service offering in their stores to enhance informed, responsible buying decisions.

The intention was to gain empirical evidence of customers' perception of the service quality (given the discrepancies that were identified in the previous report) and to establish whether store managers (who may exert some control over the service offering in the stores) and salespeople (based on their close interaction with customers) were aware of shortcomings that could be addressed to enhance the service offering to the benefit of all.

\section{CONCEPTUAL BACKGROUND}

\section{The fundamentals of service quality (SQ)}

In theory, SQ is a simple, primarily cognitive, evaluative and objective construct (Shemwell et al, 1998) that comprises of quality in fact (that is achieved when a retailer does what it promises to do) and quality in perception (that occurs when the retailer's excellence is judged within a consumer's expectations) (Kang, 2006). A service quality instrument such as SERVQUAL (Parasuraman et al, 1985) thus acknowledges consumers' judgement of process quality (the service offering during the service) as well as the output quality (the total experience after the service has been concluded) (Turley, 1990). Positive SQ judgments are instrumental in consumers' efforts to minimize perceived risk and there is ample empirical support for SQ as an antecedent of customer satisfaction (Oliver et al, 1997; Anderson et al, 1994; Parasuraman et al, 1988) and repurchase intentions (Jobber, 2010:559; Clarke, 2001). Service quality inevitably affects customers' attitudes as it results from a comparison of their expectations upon entering a store and their perception of the actual service performance in the retail context (Bahia \& Nantel, 2000; Cronin et al, 2000; Zeithaml et al, 1996). Due to the intangibility of $S Q$, it is unfortunately difficult to control (Buttle, 2004; Grönroos, 1988).

\section{Service quality instruments: an ongoing debate}

Service quality instruments were initially used to diagnose and uncover broad areas of a company's SQ shortfalls and strengths regarding executive perceptions of $S Q$ as well as tasks associated with a retailer's service delivery to consumers (Shemwell et al, 1998). In general, SQ scales reflect on customers' perceptions, prior experience and a consideration of the importance of various service elements (Clarke, 2001). As mentioned in the introduction to this report, various instruments have been developed to investigate service quality and the existence of so many instruments confirms researchers' indecisiveness regarding the best way to describe (and consequently measure) this phenomenon. Parasuraman and co workers' established SERVQUAL instrument (1985) examines evidence of tangibles, reliability, responsiveness, assurance and empathy of a store with its customers during actual shopping experiences. 
SERVQUAL is based on the disconfirmation paradigm and compares a store's perceived performance with expected performance. Despite its extensive implementation to assess $S Q$ in extant research, objections to this instrument's focus on the service delivery process and an apparent neglect of technical quality (Kang, 2006; Grönroos, 1988) resulted in the design of alternative instruments such as the one developed by Dabholkar et al (1996) that proposes a hierarchical factor structure with five dimensions that are considered central to $S Q$, i.e.: physical aspects, reliability, personal interaction, problem solving and policy. Yet another attempt to improve on service quality measurement is the topsis and service quality loss method developed by Mukherjee and Nath (2005).

The existence of so many instruments to measure service quality also signifies that the debate on service quality is far from over and that additional research is required to operationalise this intricate phenomenon. Martinez and Martinez (2010) scrutinized six prominent service quality models and their conclusions support the methodology that was followed in this research project. They concluded that researchers should dare to be more creative in the implementation of existing service quality instruments because the issue of the suitability of measuring instruments for service quality investigations in retail is not yet resolved. They maintain that creative model building in the service quality domain is at present limited by the body of existing literature. According to Martinez and Martinez (2010) there are, for example, no clear indications of how the Grönroos model $(1982,1984)$ should be operationalised, which opens the door for alternative and unique interpretations. Martinez and Martinez (2010) further state that even if researchers understand that some service quality models are formative and that others are reflective, it must be noted that all formative models have some reflective elements, which once again allows for new conceptualisations. Central to this research is their caution that service quality instruments need to be country/culture specific because service quality is an intangible construct that is difficult to interpret. One such attempt in South Africa was through an investigation by Berndt (2009) into the service quality dimensions in South African motor servicing. She too, concluded that although the statements used in traditional service quality models to describe service quality can be used, the dimensions are not clear. Consumers' judgement/ interpretation is unavoidably based on consumers' frame of reference, i.e. how the service in a specific context is rendered. Terblance and Boshoff (2006, 2001) also voiced concerns about the use of SERVQUAL and its five dimensions in a South African context. In their research, the authors distinguished between so called non-controllable and controllable elements of a total retail experience. In their conceptualisation the latter involves six dimensions that includes service quality as a specific dimension along with perceived product quality; product variety and assortment; internal store environment; product prices; store policies. Service quality is then defined in terms of the familiar responsiveness; reliability; empathy; assurance and tangibles. Based on the former arguments and different approaches to service quality, this research project did not follow the norm of one specific service quality model and did not implement an expectation-versus-perception interpretation. Dabholkar's (1996) service quality instrument was also preferred because of its focus on retail settings where a mix of merchandise and services are offered.

\section{Consumers' judgment of service quality}

Consumers in developed countries apparently judge $\mathrm{SQ}$ differently to those in developing countries. Consumers in developed countries are apparently satisfied with $S Q$ when the service offering extends benefits beyond the functional, i.e. when it is more intangible than the core service. Consumers in developing countries, however, due to personality factors that are shaped by culture related characteristics and philosophy of life tend to focus on core benefits of the service in their choice criteria, i.e. thus functional aspects. Evidence also suggests that inexperienced consumers have lower quality expectations and demonstrate a wider zone of tolerance for ineffective services, compared to consumers in developed countries (Malhotra et al, 1994). It is thus possible that inexperienced consumers may indicate that they approve of, and are impressed with a store's service offering despite fundamental shortcomings.

\section{The importance of service quality for retail}

From retailers' point of view, exceptional SQ is essential to survive in a competitive environment (Rust, Danaher \& Varki, 2000; Parasuraman et al, 1988) because service excellence differentiates one service provider from another (Dabholkar et al, 1996). Retailers that accomplish that, incidentally experience an increase in their profitability (Townsend \& Gebhardt, 1988). In order to improve, a store has to set a goal of zero defects in its service offering by implementing better systems, better staff, improved internal marketing, enhanced involvement of customers, "pleasantto-patronage" premises, better relationships among staff on all levels (Townsend \& Gebhardt, 1988) as well as superior after sales service and complaint handling (Gummeson, 1988). Unfortunately SQ is not necessarily regarded the top priority in every retail setting. Errors are sometimes considered inevitable, even expected. Various shortcomings may also obstruct optimal service delivery and cause a discrepancy between the actual service and the promised service, e.g. a gap between customers' expectations and management's perceptions and specifications of $\mathrm{SQ}$; an inability of employees to meet minimum service-performance standards; inadequate resources and poor external communication (Zeithaml et al, 1990). Consumers' risk perception may also jeopardize their $S Q$ judgements.

\section{Challenges faced by retail in terms of appliance sales}

Household appliances are relatively expensive commodities and entail short- and long-term financial con- 
sequences that consumers may find difficult to deal with in terms of households' budgets. Appliances are durable products and are expected to be operational for a considerable period of time. It also represents a complex product category because relevant technology changes continually: consumers consequently find it difficult to keep up with, and fully grasp modifications to product categories. In addition, the ownership of an appliance may even signify the status of the owner and that may affect the product type and brand purchased (Nieftagodien \& Van der Berg, 2007). The acquisition of major household appliances is therefore regarded as high-risk and may create a considerable amount of uncertainty and anxiety even more so for inexperienced consumers (Buttle, 2004; Beatty et al, 1996).

\section{Informed, responsible buying decisions}

Informed consumer decision-making refers to consumers' ability to apply relevant product knowledge during the pre purchase evaluation process to enable a responsible buying decision that reflects an understanding of the consequences of a purchase. An informed, responsible buying decision is commendable because it enhances consumer satisfaction (Erasmus \& Donoghue, 1998), limits problems during use and reduces negative emotions and unpleasant interaction with retailers and service providers. Product experience affects a consumer's ability to make informed, responsible buying decisions: the cognitive and social development that occurs during an individual's childhood provides a backdrop for knowledge and decision making skills. It is thus highly likely that consumers with limited product related consumer socialization would lack the exposure that is required to act with confidence in the market place and to make responsible buying decisions (John, 1999). Many consumers then opt for surrogate indicators such as brand name as an indication of product quality and -performance regardless of the usage situation while more experienced consumers probably demonstrate a greater ability to evaluate brands in context and within product sub categories. Ideally retail should thus plan its marketing approach for a specific context and guard against a general approach (Nilsson, 2007; Malhotra et al, 1994).

\section{RESEARCH METHODOLOGY}

The research followed a predominant quantitative approach and is exploratory and descriptive in kind. Data collection was done during May to September 2007. Three phases of a multi method strategy that involved various role players are relevant for this report: (1) store managers' assessment of "quality in fact", i.e. tangible evidence of their stores' service offering by means of an in store survey; (2) an investigation of "quality in perception", i.e. customers' perception of the service quality in appliance sales departments of prominent retail stores; (3) enquiry into personnel's recommendations to augment the service offering based their experience in the work place over time. Through liaison with industry and the cooperation of store managers, twenty branches of five prominent retailers in Tshwane, RSA, cooperated in the investigation. The selected stores were located in different parts of the metropolitan area and involved consumers across a broad socio economic spectrum.

\section{Phase 1: Store managers' assessment of the ser- vice offering}

To demonstrate that the research would be executed in a non-threatening manner, the managers of five different stores participated in the introductory phase of the investigation. Doing a survey in interview format, the researcher accompanied each of the managers through the appliance sales departments in their respective stores. The store managers verbally assessed visual evidence of their stores' service offering based on prompts provided by the researcher. She noted their remarks in accordance with a structured assessment guide/ score sheet that listed distinct attributes of elements of the service offering. A total of 60 descriptors were listed that represented ten descriptors per each of the six elements of the service offering, namely products, price, physical environment, personnel, processes and promotions. Although the content of the assessment guide was based on literature (Newman \& Cullen, 2002: 95-229) it was only finalized after a panel group discussion that involved eight experienced salespeople from different stores. During the two hour discussion that was held on a Saturday afternoon, salespeople listed and described the prominent elements of the service offering in an appliance sales context. They had to elaborate on what they regarded optimal, yet realistic, and appalling service delivery and their comments were used to finalise the scales. The items of the measuring instrument were subsequently confirmed in a recent publication by Jobber (2010:302).

Store managers' appraisals were done without intervention of the researcher other than to provide the prompts and to explain the constructs/ questions if necessary. Rating on the score sheet allowed judgements on a three-point scale, i.e. Commendable; Acceptable or Poor. Being contextualized to the setting, it was assumed that these appraisals would truly indicate managers' perceptions of the reality. An example of part of the score sheet that involved questions pertaining to one specific element, namely PERSONNEL, is provided in Table 1.

Managers' uninhibited responses were cross checked with them after the interviews in terms of the denominators on the score sheet. Responses were eventually quantified (poor=1; acceptable=2; commendable=3) to calculate total scores for each element as well as total scores for each store as an indication of store managers' awareness of shortcomings in the store. The scores remained confidential and there was no intention to generalize the scores to other stores of the same retail channel.

\section{Phase 2: Customers' perception of service quality}

Phase 2 involved customers of the respective retailers who could report on a recent buying encounter. Using a store intercept method, trained co-workers purposively recruited customers immediately after 
TABLE 1: EXAMPLE OF THE SCORE SHEET USED TO SPECIFY MANAGERS' JUDGEMENT OF "PERSONNEL"

\begin{tabular}{|c|c|c|c|}
\hline QUESTION/ PROMPT & 1: POOR & 2: ACCEPTABLE & 3: COMMENDABLE \\
\hline $\begin{array}{l}\text { How many salespeople are present in the sales department to } \\
\text { attend to customers on weekdays? }\end{array}$ & Not enough & Enough to cope & $\begin{array}{l}\text { Enough to provide } \\
\text { undivided attention }\end{array}$ \\
\hline $\begin{array}{l}\text { How many salespeople are present in the sales department to } \\
\text { attend to customers over week ends? }\end{array}$ & Not enough & Enough to cope & $\begin{array}{l}\text { Enough to provide } \\
\text { undivided attention }\end{array}$ \\
\hline Are the salespeople in the department easily identifiable? & No & They wear uniforms & $\begin{array}{l}\text { They wear uniforms } \\
\text { and name tags }\end{array}$ \\
\hline Are the salespeople generally friendly towards all customers? & No & Not necessarily & Yes, always \\
\hline $\begin{array}{l}\text { Do salespeople attend to customers who enter the department } \\
\text { immediately? }\end{array}$ & Only upon request & After a while & Yes, immediately \\
\hline $\begin{array}{l}\text { How much time, on average, do salespeople spend with custom- } \\
\text { ers? }\end{array}$ & Brief, very limited time & $\begin{array}{l}\text { As much as the salesper- } \\
\text { son can afford }\end{array}$ & $\begin{array}{l}\text { As much as customers } \\
\text { require }\end{array}$ \\
\hline $\begin{array}{l}\text { Do all the salespeople regard the customers as important irrespec- } \\
\text { tive of who they are? }\end{array}$ & Probably not & Mostly & Yes without a doubt \\
\hline $\begin{array}{l}\text { Do the salespeople make effort to inform customers about various } \\
\text { models/ options of the specific type of appliance they wish to } \\
\text { purchase? }\end{array}$ & No & $\begin{array}{l}\text { When requested, not by } \\
\text { own initiative }\end{array}$ & $\begin{array}{l}\text { Yes, as much as cus- } \\
\text { tomers will allow them } \\
\text { to }\end{array}$ \\
\hline $\begin{array}{l}\text { Can salespeople give customers their undivided attention or do } \\
\text { they have to perform other duties simultaneously? }\end{array}$ & $\begin{array}{l}\text { No, they have to attend to } \\
\text { other duties as well }\end{array}$ & $\begin{array}{l}\text { They mostly provide undi- } \\
\text { vided attention }\end{array}$ & $\begin{array}{l}\text { They always put cus- } \\
\text { tomers first and above } \\
\text { other obligations }\end{array}$ \\
\hline $\begin{array}{l}\text { Are all the salespeople in the department competent to answer } \\
\text { customers' questions? }\end{array}$ & No & Competency is not optimal & Yes without a doubt \\
\hline TOTAL SCORE & 10 & 20 & 30 \\
\hline
\end{tabular}

closure of a sales deal at pay points in various stores on weekdays as well as week ends. Willing customers completed a structured questionnaire on the spot under supervision of the researcher or an assistant. It was assumed that responses would truly reflect an actual, recent buying experience for the sake of credibility of data (Wallendorf \& Belk, 1989). An equal number of customers were recruited in each of the participating retail outlets. Between five and ten customers were recruited in a store on any specific day.

Two sections of the original questionnaire are relevant for this report, i.e. a section that requested demographic information and another that dealt with the service quality investigation (Dabholkar et al, 1996). This investigation deviated from the original gap analysis procedure that requires perceptionminus-expectation scores to determine customers' service quality judgements. This procedure was later defended in an article by Martinez and Martinez (2010), where in they criticized existing methods and proposed creative use of existing $S Q$ measuring instruments. The 28 item scale involved a directmeasure, instead of a two-part measurement approach using a 5-point Likert type scale where the opposites on the scale ranged from "definitely disagree" to "definitely agree". The traditional two part expectation/ perception measurement for service quality was rejected due to (1) the length of the questionnaire and concerns that inclusion of an additional section would jeopardize the reliability of consumers' responses, and (2) conclusions of McDougall and Levesque (1994) as well as Babakus and Boller (1992) that inclusion of an expectations rating in a service quality investigation is "inefficient and unnecessary". Minor changes were however made to the wording of the Dabholkar scale (1996) to infer the context of appliance sales, which concurs with recommendations for service quality investigations in specific contexts (Martinez \& Martinez, 2010).
Phase 3: Salespeople's recommendations to optimize the service offering

Phase 3 subjected experienced salespeople to a projective technique that encouraged them to critically assess the service offering in the stores in an imaginary capacity as managers of the stores. The researcher contacted the salespeople with the permission of their managers (Hughes, 2006; Gummeson, 2002). In order to contextualise the participants and to increase the reliability of the study (McDaniel \& Gates, 2004:36-37), only salespeople who complied with the criteria of (1) selling household appliances in any store of the five selected retailers and (2) who had a minimum of twelve months' experience in that capacity were invited to take part. All the salespeople who were invited $(\mathrm{N}=18)$ accepted, which promised a good construction of the reality in terms of adequate and trustworthy responses (Payne \& Williams, 2005; Wallendorf \& Belk, 1989). The task required the following:

"Imagine that you have been appointed as the manager of a similar department in another branch of this store where customers are not happy with the store's customer service. Describe and explain possible reasons for customers' dissatisfaction and describe how the manager should improve the service offering in order to assist customers in making informed responsible buying decisions. Describe your recommendations in as much detail as possible using a minimum of 300 words."

Willing salespeople received the task in writing and completed the task at home to allow opportunity to disclose their ideas in private, in a non-threatening manner and without being rushed (Donoghue, 2000). They were asked not to discuss the task with colleagues and were assured of the confidentiality of their contributions. The researcher collected the com- 
pleted tasks per appointment within one week.

\section{QUALITY OF DATA}

Efforts to enhance the quality of the data were exercised throughout the research project. Firstly a thorough review of literature was done to acknowledge extant research and different approaches to the service quality phenomenon. The entire research process was then planned in advance to enable conditional inter-subjectivity (Stenbacka, 2001). Industry assisted to convince retail stores to participate in the research project. Store managers were involved in phase 1 to demonstrate that the research would be done in a non threatening manner and to gain managers' approval for the subsequent phases of the research. Managers' responses were cross checked with them to ensure valid interpretation of their comments during the in store surveys. The customer questionnaire was pre tested to ensure understandability and that the length of the questionnaire would not discourage respondents or result in fatigue that may put at risk the reliability of their responses (Babbie \& Mouton, 2001, 76, 92). Internal validity, i.e. efforts to establish close interaction with the real phenomena (Gummeson, 2002; Hughes, 2006) and transferability were attended to through recruitment of 296 willing respondents who actually purchased major household appliances on the specific day when they completed the questionnaire. Data was collected under supervision on the spot in one of twenty branches of five different department stores in Tshwane, a densely populated geographic area to adequately involve representations of the constructions of reality. The researcher and the assistants were fluent in at least two of the official languages to provide assistance with the interpretation of scales if necessary (Wallendorf \& Belk, 1989). Generalization of the findings is restricted to the context of appliance sales departments of major retail channels in Tshwane, South Africa. The pretence of replication is not offered because control over the research setting would affect the underlying philosophy of this research method, i.e. to purposely select customers at point of sale without prior warning (De Ruyter \& Schol, 1998).

\section{DATA ANALYSIS AND RESULTS}

\section{Phase 1}

Store managers scored the six elements of their stores' service offering on a three-point scale. The researcher cross checked her interpretation of store managers' comments immediately after each interview to ensure that the scores reflected their assessments truthfully. The findings are presented in Table 2.

The scores for the stores were operationalised as follows to facilitate interpretation:

\section{1: Score per individual element of the service offering (maximum score: 30 ): \\ Excellent: 25 to 30; Good: 20-24; Average: 15-18; Poor: $<14$.}

2: Total score per store, i.e. integrated scores across the six elements (top score 180):

Excellent: 150+; Good: 120-149; Average: 90-119; Poor: $\leq 89$.

3: Integrated scores for specific elements of the service offering across the five stores (maximum: 150):

Excellent: 125+; Good: 100-124; Average: 75-99; Poor: $\leq 74$.

Scores for individual elements of the service offering Only one of the stores obtained scores $\geq 25$ for all six elements of the service offering, i.e. indication that all elements are presented excellently. Two other stores obtained excellent assessments for one element of the service offering only, both in terms of the physical environment of the store.

Total score per store, i.e. integrated scores across the six elements Results (Table 2) suggest that stores tend to attend to certain elements of the service offering more meticulously, for example, compared to the other elements of the service offering, the physical environment was judged more favourably. A score of 120/150 suggests that in general, the physical environment of stores is good, which indicates effort to create an appealing, pleasurable in store environment. Promotions are however apparently neglected. The total score across the stores $(89 / 150)$ suggest that this element is poorly presented, which may impact negatively on stores' efforts to attract customers and to convey product information. In store promotions have the potential to offer educational value; to attract attention and to indirectly enhance informed responsible buying decisions.

Only one of the five stores performed excellently in terms of its integrated score for all the elements of the service offering. Three elements of the service offering mainly contributed to lower integrated scores for

TABLE 2: STORE MANAGERS' ASSESSMENT OF THE SERVICE OFFERING IN THEIR STORES

\begin{tabular}{|c|c|c|c|c|c|c|}
\hline \multirow{2}{*}{$\begin{array}{c}\text { ELEMENTS OF THE SERVICE } \\
\text { OFFERING }\end{array}$} & \multicolumn{5}{|c|}{ Scores per element, per store } & \multirow{2}{*}{$\begin{array}{l}\text { Total for the element } \\
\text { (Maximum score: } 150)^{3}\end{array}$} \\
\hline & Store 1 & Store 2 & Store 3 & Store 4 & Store 5 & \\
\hline Physical environment & 26 & 18 & 26 & 20 & 30 & 120 \\
\hline Personnel & 21 & 19 & 23 & 24 & 30 & 117 \\
\hline Price & 20 & 20 & 20 & 24 & 27 & $\overline{111}$ \\
\hline Products & 20 & 19 & 22 & 19 & 29 & 109 \\
\hline Processes & 19 & 17 & 22 & 20 & 28 & 106 \\
\hline Promotions & 13 & 14 & 11 & 21 & 30 & 89 \\
\hline Maximum total score per element ${ }^{1}$ & 30 & 30 & 30 & 30 & 30 & 150 \\
\hline${\text { Total score per store (Maximum: } 180)^{2}}^{2}$ & 119 & 107 & 124 & 128 & 174 & \\
\hline
\end{tabular}


the stores, namely processes, promotions and products. In an ideal setting where informed, responsible buying decisions are endorsed, these elements of customer service are crucial because evidence of guarantees, after sales support, consumer protection, communication of product information, product variety and quality are implied.

\section{Phase 2}

Demographic information of the customers A total of 296 useful questionnaires were completed by customers in the various stores, the majority being female (female: $n=201 / 68.3 \%$; male: $n=93 / 31.6 \%$ ) while the ages ranged from 20 to 62 years $(20-25$ years: $n=47 / 15.9 \% ; 26-35$ years: $n=75 / 25.3 \%$; 36 45 years: $n=100 / 33.8 \%$; $46-60$ years: $n=65 / 22.0 \%$; $>60$ years: $n=7 / 2.4 \%$; missing data: $n=2 / 0.6 \%$ ). Questionnaires that were incomplete in terms of one or more of the sections that were fundamental to perform the statistical procedures were discarded $(n=35)$.

Respondents' judgement of service quality The relevance of the factors of the selected service quality scale (Dabholkar et al, 1996) and its reliability in terms of the context of this research was assessed through factor analysis. Responses $(\mathrm{N}=296)$ were subjected to exploratory factor analysis using squared multiple correlations as initial communality estimates with direct oblimin rotation. A Scree test revealed a collapse of the initial five-factor scale into two dimen- sions, which were then subjected to oblique rotation. During the interpretation of the rotated factor pattern, all items that loaded high on one dimension but low on the others were identified to produce a factorloading matrix. Items that loaded high on more than one dimension were eliminated from the factorloading matrix, resulting in near-zero correlations between some of the remaining items. Because some of the items loaded high onto dimensions that were not originally assigned in the Dabholkar scale (1996), some items had to be re-assigned. The reduction in the number of factors from five to two; the deletion of certain items and the re-assignment of certain items required a re computation of alphas and item-to-total correlations as well as the re examination of the factor structure of the reduced item pool. A repeated process identified a final pool of 25 items that represented two distinct dimensions that contained twelve and thirteen attributes respectively. The relevant Cronbach Alpha coefficients of 0.93 and 0.86 suggest high levels of reliability. Rotated factor loading matrices and alpha values for the eventual instrument are presented in Table 3 . The newly identified factors were labeled in accordance with the interpreted meaning of the relevant attributes.

The first factor, i.e. supportiveness, contains 12 attributes and integrates four factors of the original scale, namely reliability, personal interaction; problem solving and policy. Most of the 13 attributes/items contained in the second dimension, i.e. impressiveness

\section{TABLE 3: FACTOR LOADINGS FOR THE ELEMENTS OF SQ THAT WERE IDENTIFIED THROUGH} FACTOR ANALYSIS

\begin{tabular}{|c|c|c|}
\hline \multirow{2}{*}{ Variable } & Factor 1 & Factor 2 \\
\hline & Supportiveness & Impressiveness \\
\hline Prompt attention to customers & 0.973 & 0.156 \\
\hline Personal attention & 0.930 & 0.115 \\
\hline Store keeps its promises & 0.823 & 0.043 \\
\hline Courteous salespeople & 0.760 & 0.097 \\
\hline Supplementary items create good impression & 0.755 & 0.027 \\
\hline Salespeople instill confidence & 0.660 & 0.146 \\
\hline Correct transactions from the start & 0.653 & 0.070 \\
\hline Customers trust dealings with store & 0.597 & 0.249 \\
\hline Store lay out makes it easy to find appliances & 0.593 & 0.168 \\
\hline Salespeople handle complaints themselves & 0.484 & 0.273 \\
\hline Merchandise available when wanted & 0.381 & 0.229 \\
\hline Neatly dressed salespeople & 0.351 & 0.204 \\
\hline Salespeople have sufficient knowledge & 0.074 & 0.675 \\
\hline Store will return or exchange goods & 0.040 & 0.597 \\
\hline Convenient parking & 0.128 & 0.590 \\
\hline Error free sales transactions & 0.048 & 0.586 \\
\hline Visually pleasing impression & 0.049 & 0.584 \\
\hline Accepts major credit cards & 0.021 & 0.562 \\
\hline Convenient operating hours & 0.040 & 0.561 \\
\hline Store lay out is logical & 0.113 & 0.531 \\
\hline Salespeople keep customers informed & 0.003 & 0.520 \\
\hline Pleasing environment & 0.106 & 0.502 \\
\hline Salespeople always willing to help & 0.228 & 0.467 \\
\hline Offers enough credit options & 0.126 & 0.463 \\
\hline Modern impression & 0.205 & 0.314 \\
\hline$\%$ Variance explained & 40.00 & 4.70 \\
\hline Cronbach Alpha & 0.93 & 0.86 \\
\hline Mean & 3.88 & 4.08 \\
\hline Standard Deviation & 0.80 & 0.50 \\
\hline
\end{tabular}

Customer service in appliance sales departments of selected prominent retail outlets: Store manager, sales personnel and customer perspectives 
can be associated with effort to satisfy customers' expectations and to distinguish one store from another. The content relates to the specific factor of the original scale that addressed physical aspects in terms of two sub factors, i.e. appearance and convenience.

The respective means of 3.88 and 4.08 (maximum: 5.0) suggest above average positive judgements by customers of both factors of service quality. Although the means for the two factors of the scale indicate some room for improvement in the service offering, the means are probably too high to alert retailers to seek redress. From retailers' perspective the findings of this research would in all probability indicate that they are doing well and that there is no pressure to improve. This positive service quality judgement does however not necessarily confirm service excellence: consumers generally make judgements within their own expectations frameworks. Satisfaction with the service offering may therefore merely indicate - as suggested by Malhotra and co workers (1994) as well Henry and Caldwell (2006) - that consumers' expectations are not high. This could be attributed to limited knowledge as was found in the prior study (Erasmus \& Gothan, 2008) and/ or the fact that consumers have never been exposed to better alternatives that could have influenced their expectations upon which their judgments were based.

\section{Phase 3}

The analysis of qualitative data is described as being more explicitly interpretative, creative and personal, but still systematic and careful (Sandelowski \& Barosso, 2003; Stenbacka, 2001). AtlasTi, a computer program for visual qualitative data analysis, management and theory building (Version WIN 4.2) was used to do content analysis of the written responses of salespeople (Babbie \& Mouton,
2001:278). Systematic coding of the transcribed text was done first (Northcut \& McCoy, 2004) and open codes were assigned to text as coding progressed. Families were created to group coherent items. Links between segments of text were then created. The coded text revealed salespeople's pre occupation with certain elements of the service offering and it was hence decided to do frequency calculations of concepts mentioned. Table 4 summarizes the elements of the service offering that were mentioned spontaneously in descending order of frequency mentioned to illustrate salespeople's proposals to enhance retailers' service offering and their pre occupation with certain elements.

Salespeople's high regard for their own role in terms of efforts to enhance the service offering in the stores was evident. Without exception every participant mentioned the contribution of salespeople first in terms of efforts that should be made to encourage informed responsible buying decisions. Salespeople's own contribution was also referred to most frequently $(n=121)$ than any other element of customer service. A personal trait, i.e. attitude, was identified as a crucial pre condition for salespeople to provide optimal consumer facilitation. Every participant referred to this attribute more than once in their proposals. They further recommended that enough salespeople should be available in the stores to attend to customers' needs (commenting that it is not always the case) e.g.

"Stores should employ and deploy enough competent sales assistants with a positive attitude in the stores to assist customers who enter the stores"

Personnel's competence and their product knowledge were mentioned as important pre requisites for service excellence. Reference to "training" confirms these recommendations. Mention of a clear job description by a few, probably indicates that sales per-

TABLE 4: PERSONNEL'S REFERRAL TO ELEMENTS OF THE SERVICE OFFERING IN THE PROJECTIVE TECHNIQUE ( $\mathrm{N}=18)$

\begin{tabular}{|c|c|c|c|}
\hline $\begin{array}{l}\text { Elements of the service } \\
\text { offering }\end{array}$ & $\begin{array}{l}\text { Attributes mentioned, i.e. secondary concepts that pertain to } \\
\text { elements of the service offering }\end{array}$ & $\begin{array}{c}\text { Frequency }(n)^{*} \text { men- } \\
\text { tioned }\end{array}$ & Total \\
\hline \multirow{7}{*}{ Personnel } & Attitude of salespeople & 44 & \multirow{7}{*}{121} \\
\hline & Availability of salespeople & 20 & \\
\hline & Competence to handle transactions & 17 & \\
\hline & Knowledgeable personnel & 16 & \\
\hline & Evidence of training & 10 & \\
\hline & Motivated to assist customers & 9 & \\
\hline & Clear job description & 5 & \\
\hline \multirow{5}{*}{ Processes } & Redressing done & 8 & \multirow{5}{*}{26} \\
\hline & Transactions handled to customers' satisfaction & 7 & \\
\hline & Assistance with additional services, e.g. installation & 6 & \\
\hline & Delivery arrangements & 4 & \\
\hline & Provision of guarantees & 1 & \\
\hline \multirow{3}{*}{ Products } & Availability of products & 14 & \multirow{3}{*}{18} \\
\hline & Quality of products & 3 & \\
\hline & Variety of products offered & 1 & \\
\hline \multirow{2}{*}{ Price } & Correct prices on items & 7 & \multirow[b]{2}{*}{11} \\
\hline & Proper display of prices & 4 & \\
\hline Physical environment & Pleasing environment & 7 & 7 \\
\hline Promotion & Availability as advertised & 6 & 6 \\
\hline
\end{tabular}

Frequencies exceed $N=18$ whenever participants mentioned particular aspects more than once 
sonnel sometimes have to perform a variety of tasks that may be counterproductive, confusing, frustrating or that may interfere with what they regard important. Aspects of customer service that are associated with peace of mind (processes) and reduced frustration, such as error free transactions and assistance with delivery and installation were also mentioned more than once by every participant $(n=26)$. This coincides with consumers' apparent regard for the human aspect of customer service (Malhotra et al, 1994) and the identification of supportiveness as a prominent dimension of service quality (Table 3 ). Only one participant mentioned guarantees as an important determinant of optimal service delivery. Referral to "opportunity for redress" suggests the same. Guarantees could however also be regarded as the responsibility of industry and to a lesser extent, the concern of the store. Products were referred to in terms of three concepts of which the "availability of products" was mentioned more frequently than "product quality". This suggests a supply-demand concern and a possibility that customers not necessarily get what they want when they enter the stores in the first place. This is regrettable because product knowledge tests revealed that consumers not necessarily possess the relevant product knowledge required to handle product evaluation and -choice well (Erasmus \& Gothan, 2008). If consumers then have to settle for products that are available in store rather than to select products of choice, they have to be assisted by competent salespeople and be informed about product alternatives.

Salespeople apparently do not necessarily regard price highly in terms of their perception of an enhanced service offering. Those who mentioned price in their proposals indicated that prices should be displayed visibly and correctly to reduce frustration and to prevent confusion. No mention was made of affordability in the projective technique.

Limited reference to the physical environment may indicate that salespeople are not necessarily aware of shortcomings or that the environment could be more conducive for informed, responsible buying decisions. It may therefore indicate that the physical surrounding in the stores is generally regarded satisfactory in terms of what is offered in department stores.

Figure 1 presents the AtlasTi configuration of participants' referrals to elements of the service offering that should be attended to in terms of an augmented service offering.

\section{DISCUSSION OF THE FINDINGS}

Three assessments of the service offering in appliance sales departments of prominent retail stores in Tshwane, RSA are relevant, i.e. (1) store managers' assessment of the service offering, with specific reference to tangible, controllable evidence of the service offering of their own stores that may induce customers' service quality perceptions; (2) customers' perception of the service quality, specifically in terms of two newly identified factors of service quality; and (3) experienced salespeople's proposals to enhance the service offering in their stores if given the opportunity

\section{Customer Service}

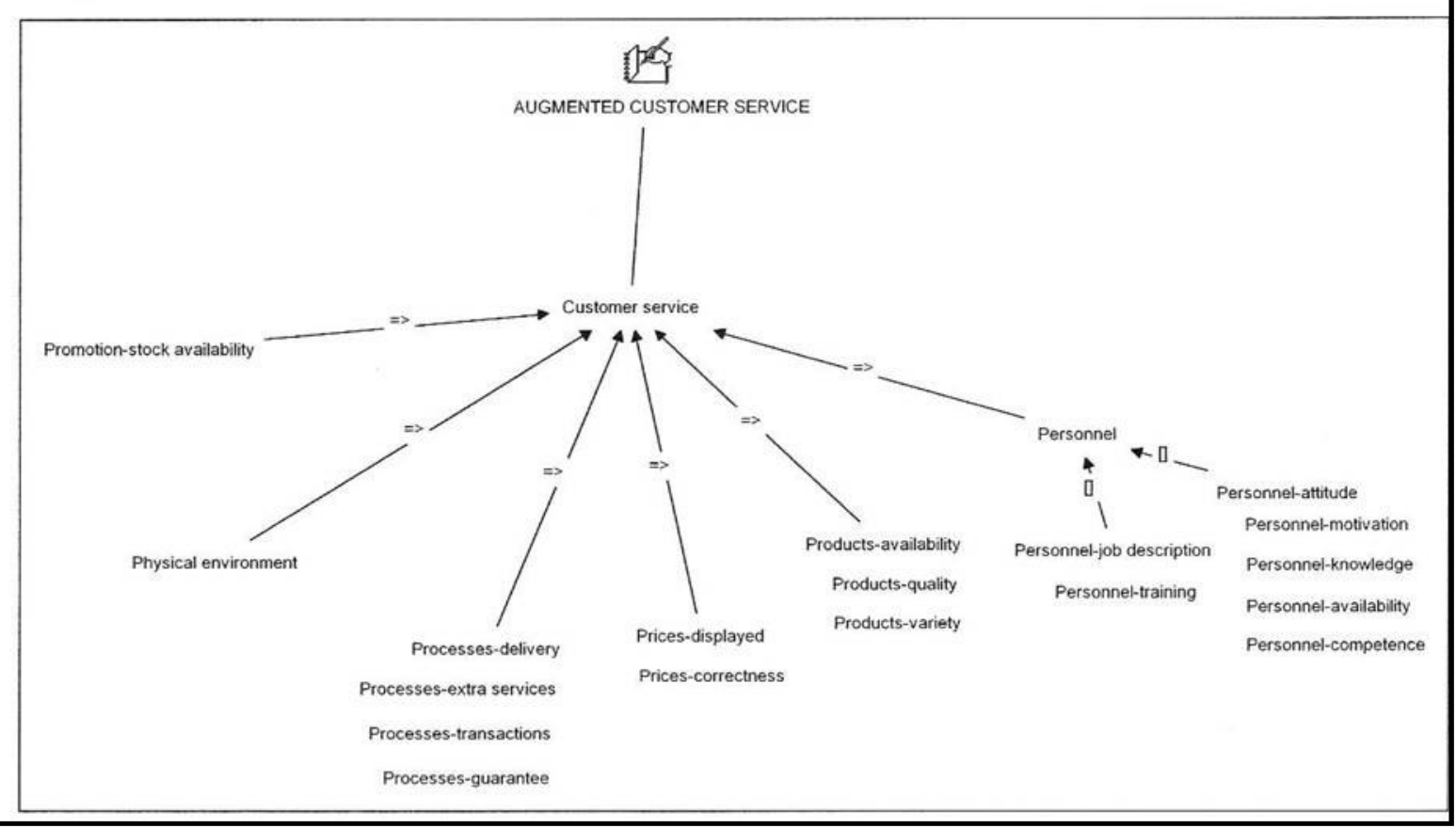

FIGURE 1: A SCHEMATIC PRESENTATION OF SALESPEOPLE'S SUGGESTIONS FOR AUGMENTED SERVICE OFFERING 
to do so to enhance informed, responsible buying decisions, based on their day to day experiences.

Store managers' assessments indicated a disparity in the service offering of the selected stores in terms of the stores' attention to various elements of the service offering. Only one of the five stores was rated excellent by its store manager in terms of the integrated score for all the elements of its service offering, while two stores were rated good and two were rated average. Managers' appraisals of their own stores reflect negatively on the majority of the stores' efforts. Pertinent shortcomings came to the fore: price related aspects of the service offering are apparently attended to more meticulously than product-, promotion- and process related attributes which are important in terms of opportunity to inform and educate consumers prior to the decision-making stage. While in general, the physical environment is apparently attended to better than other elements of the service offering of all the retailers, efforts that are process related and that are meant to instil confidence and to protect the interest of customers are apparently neglected. This is to the detriment of informed, responsible buying decisions.

Customers' positive appraisals of service quality contradicted store managers' assessment of tangible evidence of the service offering that are fundamental in terms of the eventual service offering. Based on a single perception measurement only, customers' perception of the service quality in the retail stores seemed predominantly positive for both the newly identified facors of service quality. Findings revealed a collapse of the original five factor scale to a simpler two-factor scale. The newly identified factors, i.e. supportiveness and impressiveness indicate a clear distinction between aspects that contribute to fundamentals of a service offering from the perspective of a customer, i.e. support and aspects that relate to efforts to distinguish a store's offering from those of competitors. This confirms concerns (Malhotra et al, 1994 ) that a generalised approach to services in retail would be unsuccessful and that the context of the research should be accounted for. The service quality investigation suggests a more holistic, less intricate judgement by consumers where certain factors of service quality are integrated and not necessarily judged per se. From consumers' point of view, the service quality in retail stores' appliance sales departments seem adequate. These findings may unfortunately create a myopia that could discourage retailers to improve their service offering.

During phase 3 , salespeople's proposals confirmed the shortcomings that were identified through managers' appraisals. It is encouraging that salespeople highly regarded their own potential - in terms of being available to attend to customers' needs; possessing specific personal attributes such as a positive attitude and being competent - in terms of efforts to enhance the service offering. Salespeople's spontaneous referral to apt product knowledge and regular training signifies that salespeople's role in terms of service excellence should be acknowledged and that they should be encouraged and provided with opportunity for training. Personnel's recommendations seem valid considering customers' lack of product knowledge as reported previously.

Findings therefore revealed that customers' service quality assessment neither identified shortcomings in retail, nor provided retailers with truthful evidence of the excellence of their performance. In the context of this research, customers' positive service quality perceptions seem to be misleading because managers' appraisals of their own stores were less favourable. They identified specific shortcomings in the service offering that were later confirmed by salespeople's uninhibited proposals on how the service offering could be augmented to enhance informed responsible buying decisions. This matter deserves further attention considering the complexity of the product category and the risk involved.

\section{IMPLICATIONS FOR RETAIL}

This study indicates two pertinent areas of concern that have implications for retail. Firstly, personnel identified pertinent shortcomings in the service offering of retail stores although customers' service quality judgements were positive. Store managers identified shortcomings in terms of the tangible evidence of the service offering that pertain to customer care/ support and consumer education (i.e. process-; personnel-; promotion related evidence). Store managers' cognisance of these shortcomings and their spontaneous disclosure of inadequacies should be appreciated. This probably indicates that they would be in a position to intervene if a store's policies and marketing audit allow them to. Affirmation of these shortcomings in salespeople's recommendations for the optimisation of the in store environment in order to create opportunity for informed, responsible buying decisions also indicate their potential to contribute to service excellence. Close interaction between customers and sales personnel provides excellent opportunity to augment a store's service offering and therefore personnel's contribution in terms of retailers' service excellence should be noted.

Secondly, retailers should take note of consumers' apparent ignorance when purchasing complex products. From the viewpoint of the discipline of Consumer Science, the ideal would be for retailers to accept the challenge and that they gain competitiveness in the market place through a more altruistic approach, i.e. to assist and support consumers, rather than abiding with economic marketing principles. Newman and Cullen $(2002: 40,88)$ advise that, in order to survive in a competitive environment and to surpass competitors, a retailer has to provide much more than what is considered sufficient. According to the findings of this study, service excellence may be based on elements of the service offering that are neglected at present. It seems as if all retailers' efforts are focussed on price, product and elements of the physical environment, which may result in a "sameness" that fail to elevate individual stores' service offering. 


\section{LIMITATIONS OF THE RESEARCH}

Findings of the research reflect on specific stores in a specific geographic area and can not be generalised in terms of all the stores of participating channels or to all the department stores in the RSA. A store intercept method is difficult to execute: it took some convincing to get customers to complete the questionnaires in the store.

\section{SUGGESTIONS FOR FURTHER RESEARCH}

A follow-up project with an interpretivistic approach, for example panel discussions could be done in various parts of South Africa to encourage vigorous elicitation of thought concerning consumers' personal experiences of customer service in different areas to identify and describe consumers' specific needs in terms of retailers' service offering.

\section{REFERENCES}

ANDERSON, EW, FORNELL, C \& LEHMAN, DR. 1994. Customer satisfaction, market share and profitability. Findings from Sweden. Journal of Marketing 3 (58):53.

BABAKUS, E \& BOLLER, GW. 1992. An Empirical Assessment of the SERVQUAL scale. Journal of Business Research 24(1):253-268.

BABBIE, E \& MOUTON, J. 2001. The practice of social research. S.A. Ed. Cape Town. Oxford University Press.

BAHIA, K \& NANTEL, J. 2000. A reliable and valid measurement scale for the perceived service quality of banks. International Journal of Bank Marketing 2 (18):84-91.

BEATTY, SE, MAYER, M, COLEMAN, JE, REYNOLDS, KE \& LEE, J. 1996. Customer-sales associate retail relationships. Journal of Retailing 72(3):223247.

BERNDT, A. 2009. Investigating service quality dimensions in South African motor vehicle servicing. African Journal of Servicing Management 1(1):001009. April.

BISSEKER C. 2004. The black middle class. Breaking class. Financial Mail, October 8.

BLACK SPENDING PEWER ON THE WAY UP 2004. Available online. URL: http:// www.southafrica.info/doing_business/trends/ empowerment/buppie.htm Accessed 2 November 2004.

BUTTLE, F. 2004. Customer relationship management, concept and tools. Oxford. Elsevier Butterworth-Heinemann.

CHAN, TS \& CUI, GC. 2004. Consumer attitudes toward marketing in a transitional economy: a replication and extension. Journal of Consumer Marketing 21(1):10-26.

CLARKE, G. 2001. Confirming satisfaction as an attitude within the service-buying process. Journal of Consumer Behaviour 2(1):111-124.

CRONIN, JJ, BRADY, MK \& HULT, GTM. 2000. Assessing the effects of quality, value and customer satisfaction on consumer behavioral intentions in service environments. Journal of Retailing 2(76):193218.
CRONIN, JJ, \& TAYLOR, SA. 1992. Measuring service quality: a reexamination and extension. Journal of Marketing (56):55-68.

DABHOLKAR, PA, THORPE, DI \& RENTZ, JO. 1996. $A$ measure of service quality for retail stores. Scale development and validation. Journal of the Academy of Marketing Science 1(24):3-16.

DAKORA, AN, BYTHEWAY, AJ \& SLABBERT, A. 2010. The Africanisation of South African retailing: $A$ review. African Journal of Business Management 4 (5):748-754.

DE RUYTER, K \& SCHOLL, N. 1998. Positioning qualitative market research. Reflections from theory and practice. Qualitative Market Research. An International Journal 1(1):7-14.

DONOGHUE, S. 2000. Projective techniques in consumer research. Journal of Family Ecology and Consumer Sciences 28:47-53.

ERASMUS, AC \& DONOGHUE, S. 1998. Consumer satisfaction - an unattainable ideal? Journal of Family Ecology and Consumer Sciences 26:35-42.

ERASMUS, AC \& GOTHAN, AJ. 2008. Customers' judgment of the customer service in appliance sales departments in an emerging economy. International Journal of Consumer Studies 32:639-647.

GRÖNROOS, C. 1988. Service quality. The six criteria of good perceived service. Review of Business 3 (9): 10.

GUMMESON, E. 1988. Service quality and product quality combined. Review of Business 3(9):14.

GUMMESON, E. 2002. Practical value of adequate marketing management theory. European Journal of Marketing 3(36):325-349.

HAUPT, P. 2001. The SAARF universal living standards measure (SU-LSM) - 12 years of continuous development. Available online. URL: http:// www.saarf.co.za Accessed 1 November 2004.

HENRY, PC \& CALDWELL, M. 2006. Selfempowerment and consumption. European Journal of Marketing 40(9/10):1031-1048.

HUGHES, T. 2006. New channels/old channels, customer management and multi-channels. European Journal of Marketing 40(1/2):113.

JOBBER, D. 2010. Principles and Practice of Marketing. $6^{\text {th }}$ Ed. London. McGraw-Hill.

JOHN, DR. 1999. Consumer socialization of children. A retrospective look at twenty-five years of research. Journal of Consumer Research 3(26):183-201.

KANG, G. 2006. The hierarchical structure of service quality, integration of technical and functional quality. Managing Service Quality 1(16)37-50.

MALHOTRA, NK, ULGADO, FM, AGARWAL, J \& BAALBAKI, IB. 1994. International services marketing. A comparative evaluation. International Marketing Review 2(11):5-16.

MARTINEZ, JA \& MARTINEZ, L. 2010. Some insights on conceptualizing and measuring service quality. Journal of Retailing and Consumer Services 17:2942.

Mc DANIEL, C \& GATES, R. 2004. Marketing Research Essentials. Hoboken ,N J. John Wiley.

MCDOUGALL, G \& LEVESQUE, T. 1994. A revised review of service quality dimensions: An empirical investigation. Journal of Professional Services Marketing 11(1):189-210.

MUKHERJEE, A \& NATH, P. 2005. An empirical as- 
sessment of comparative approaches to service quality measurements. Journal of Services Marketing 19 (3):174-184.

MYERS, H. \& ALEXANDER, N. 2007. The role of retail internationalisation in the establishment of a European retail structure. International Journal of Retail Distribution Management 35(1):6-19.

NEWMAN, AJ \& CULLEN, P. 2002. Retailing: Environment and Operations. London. Thomson Learning.

NIEFTAGODIEN, S. \& VAN DER BERG, S. 2007. Consumption patterns and the Black middle class: The role of assets. Bureau of Economic Research, 2 (7):1-10.

NILSSON, D. 2007. A cross-cultural comparison of self-service technology use. European Journal of Marketing 3/4(41):367.

NORTHCUT, N \& McCOY, D. 2004. Interactive Qualitative Analysis. A Systems Method for Qualitative Research. London. Sage Publications.

OLIVER, RL, RUST, RT \& VARKI, S. 1997. Customer delight. Foundations, findings and managerial insight. Journal of Retailing 73(3):311-336.

PARASURAMAN, A, ZEITHAML, VA \& BERRY, LL. 1988. SERVQUAL, A multiple-item scale for measuring consumer perceptions of service quality. Journal of Retailing 64(1):12-40.

PARASURAMAN, A, ZEITHAML, VA \& BERRY, LL. 1985. A conceptual model of service quality and its implications for future research. Journal of Marketing 49:41-50.

PARK, Y \& STERNQUIST, B. 2008. The global retailer's strategic position and choice of entry mode. International Journal of Retail Distribution Management 36(4):281-299.

PAYNE, G \& WILLIAMS, M. 2005. Generalization in Qualitative research. Sociology 2(39):295-314.

DREARDON, J, MILLER, C, VIDA, I \& KIM, I. 2005. The effects of ethnocentrism and economic development on the formation of brand and ad attitudes in transitional economies. European Journal of Marketing 39(7/8):737-754.

RUST, RT, DANAHER, PJ \& VARKI, S. 2000. Using service quality data for competitive marketing decisions. International Journal of Service Industry 5 (11):438.

SANDELOWSKI, M \& BARROSO, J. 2003. Classifying the findings in qualitative studies. Qualitative Health Research 7(13):905-923.
SHEMWELL, DJ, YAVAS, U \& BILGIN, Z. 1998. Customer service provider relationships, an empirical test of a model of service quality, satisfaction and relationship-orientated outcomes. International Journal of Service Industry Management 2(9):155-168.

STENBACKA, C. 2001. Qualitative research requires quality concepts of its own. Management Decision 7 (39):551-555.

TERBLANCHE, NS \& BOSHOFF, C. 2001. Measuring consumer satisfaction with some of the controllable elements of the total retail experience: An exploratory study. South African Journal of Business Management 32(2):35-42.

TERBLANCHE, NS \& BOSHOFF, C. 2006. A generic instrument to measure customer satisfaction with the controllable elements of the in-store shopping experience. South African Journal of Business Management 37(3):1-15.

TOWNSEND, PL \& GEBHARDT, JE. 1988. Quality, $20^{\text {th }}$ Century snake-oil. Review of Business 3(9):6-11.

TURLEY, LW. 1990. Strategies for reducing perceptions of quality risk in services. Journal of Services Marketing 3(4):5.

WALLENDORF, M \& BELK, RW. 1989. Assessing trustworthiness in naturalistic consumer research. Interpretive Consumer Research 69-84. Elizabeth C. Hirschman, ed. Provo, UT: Association for Consumer Research.

WILLIAMS, TG. 2002. Social class influences on purchase evaluation criteria. The Journal of Consumer Marketing 2/3(19):249.

WINSTED, KF. 1997. The service experience in two cultures, a behavioral perspective. Journal of Retailing 3(73):337-360.

WORTLEY, B \& TSHWAEDI, M. 2002. Segmentation in South African marketing and advertising industries. Portfolio committee on communications hearings into transformation of the advertising and marketing industry. Appendix 10.2. Available online. URL: http:// www.gcis.gov.za/docs/portcom/02segmentsub.html Accessed 15 October 2004.

ZEITHAML, VA, BERRY, LL \& PARASURAMAN, A. 1996. The behavioural consequences of service quality. Journal of Marketing 60(2):31.

ZEITHAML, VA, PARASURAMAN, A \& BERRY, LL. 1990. Delivering quality service. Balancing customer perceptions and expectations. London. The Free Press. Collier Macmillan. 